\title{
Willingness to pay of the native chicken eggs in urban supermarket: evidence from Semarang, Indonesia
}

\author{
Desy Wulandari", Wiludjeng Roessali, and Kustopo Budiraharjo \\ Faculty of Animal and Agricultural Sciences, Diponegoro University, Semarang, Indonesia \\ *Correspondence email: w.desy24@gmail.com
}

\section{ARTICLE INFO}

- Research Article

Article History

Received 19 June 2020

Accepted 14 July 2020

Published 31 October 2020

\section{Keywords}

CVM; native chicken eggs;

modern market, willingness to pay

JEL Classification

D12, Q02; Q13

\begin{abstract}
Urban people show a certain preference in consuming native chicken eggs products. This research aims to identify market segmentation and analyze willingness to pay (WTP) for consumers of native chicken eggs. The research was conducted at four places in the supermarket in Semarang city. Respondents as many as 100 people were selected using an accidental sampling method. Data were analyzed by descriptive and Contingent Valuation Method (CVM). The results show that consumer market segmentation can explain the analysis of WTP. Marked characteristics of consumers of the native chicken egg include in between $25-50$ years old $(50 \%)$, female $(89 \%)$, go shopping as family motivation (70\%), and purchasing once a week (85\%). $87 \%$ of respondents show the WTP in the range of 5 to $20 \%$ above the existing price. The maximum WTP is 23.45 thousand rupiahs per pack. The highest of maximum WTP found in rattan packaging in Superindo is 26.79 thousand rupiahs per pack. The highest WTP aggregation value is found in Gelael with mica packaging at the 373 thousand rupiahs. Furthermore, supermarkets can contribute to apply quality standards for native chicken eggs, and protect the interests of consumers.
\end{abstract}

Citation: Wulandari, D., Roessali, W., \& Budiraharjo, K. (2020). Willingness to pay of the native chicken eggs in urban supermarket: evidence from Semarang, Indonesia. Journal of Socioeconomics and Development, 3(2), $79-88$. https://doi.org/10.31328/jsed.v3i2.1418

ISSN 2615-6075 online; ISSN 2615-6946 print (C)WG Press, 2020

\section{INTRODUCTION}

The native chicken eggs are a source of animal protein with delicious and highly nutritious flavors (Yang, 2018). The native chicken eggs are produced from native chicken species that have different characteristics from purebred chicken eggs. Native chickens is a term given to chickens raised with natural food such as bran, corn, insect, seeds, or rice that are easily found in a farmland environment. Native chickens are not fed any fodder containing chemicals. Thus, the native chicken grows in more natural environments and it takes longer raised periods than the purebred chickens. Native chicken eggs also have characteristics and shapes that are much different from purebred chicken eggs that are usually consumed for daily food. The average weight size of native chicken eggs is 34 to 45 gram/egg, compared to purebred chicken which is 50 to 70 gram/egg (Astawan \& Kasih, 2008). Nutritional value of native chicken eggs contains protein $(12.80 \%)$, fat $(11.50 \%)$, carbohydrates $(0.75 \%)$, water $(74 \%)$ (Hidayat \& Asmarasari, 2015). When compared to purebred chicken eggs, native chicken eggs have ingredient value per 100 grams containing 174 calories, 10.8 grams of protein, $4.9 \mathrm{mg}$ of iron and $61.5 \mathrm{~g}$ of retinol or vitamin A. Besides, local native 
chicken eggs tastes better and fishy is lower (Johnson et al., 2020).

As the public knowledge increases, people are increasingly aware of the nutritional need needed by the human body and the nutritional need of families. Today, native chicken eggs are considered by the community to be consumed because it contains more the vitamin E nutrition and a 2.5 times omega-3 fat content more than purebred chicken eggs Lupu, Wuri, \& Detha (2016). Omega 3 is a linoleic acid that functions for the formation of sphingomyelin and the structural components of nerve cells (myelin). Omega 3 affects the performance of brain development, the nutrients that are important for the growth of the brain and the eyes of children (Diana, 2013). Vitamin E works to maintain the health of various tissues in the body, in terms of skin tissues, eyes, red blood cells to the liver. Besides, it can also protect the human lungs from air pollution, which this health value is related to the work of vitamin $E$ in the body as a natural antioxidant compound (Yuniati \& Almasyhuri, 2012). Such nutritional contents make the price of native chicken eggs more expensive than purebred chicken eggs (Fadilah \& Fatkhuroji, 2013).

The city of Semarang is the capital of the province of Central Java. It has even been one of the metropolitan cities in Indonesia. Semarang has become the center of economic activities in central Java, lead to trade, education, services, and tourism supported by the quality of human resources. The population of Semarang city is approximately 1.6 million people, comprising 793 thousand males and 802 thousand females. A city with a population of more than 1 million is assumed to be a high level of food consumption (BPS Kota Semarang, 2015).

Cities that have a large population and welleducated people among them influence public knowledge about the importance of a healthy lifestyle. Native chicken eggs are one of the choices by the community to meet nutritional intake needs. Cities that have a large population and well-educated people among them influence public knowledge about the importance of a healthy lifestyle. Native chicken eggs are one of the choices by the community to meet nutritional intake need. The existence of a large number of supermarkets in the city of Semarang is very helpful in meeting people's need for a variety of consumption.

At present, the development of modern markets such as supermarkets expends rapidly and has shifted the role of traditional markets. Some people, especially those who live in urban areas have fulfilled their daily need or household need by shopping in modern markets. Modern markets display more benefits for consumers because they are easily found in many places to shop with enjoyable facilities. Modern markets or supermarkets successfully capture the need of consumers, are able to meet the desires and tastes of consumers, while traditional markets are slow to respond to changes in consumer shopping behavior that is increasingly dynamic (Pramudiana, 2017). Consumers prefer to shop at supermarkets because of the practical payment system, comfortable spaces and a wider variety of products available (Fernandez, 2020). As a result, consumers' shopping behavior also changes and begins to shift to modern markets.

The concept of willingness to pay (WTP) is the maximum price that consumers are ready to pay for goods and services or it measures the value that consumers want to pay for goods and services. In other words, it can be interpreted to measure the benefits of a product from consumers (Bishop \& Timmins, 2019). Consumers who are increasingly aware of the nutritional need and advantages of native chicken eggs want these benefits by the price incurred to obtain native chicken eggs. This shows that consumers are willing and able to pay a higher price of native chicken eggs than the normal price. The magnitude of the price that is willing to be paid by native chicken egg consumers needs to be known to calculate the price factor for native chicken egg producers. Native chicken eggs can be obtained from various supermarket places. Semarang City offers many supermarkets that offer choices for people to meet a variety of need. This can generate the level of consumption and the WTP for native chicken eggs.

This research aims to identify market segmentation of native chicken eggs and to analyze WTP for consumers in the supermarket in Semarang city, Indonesia.

\section{RESEARCH METHOD}

The study was conducted in February - March 2020 in four supermarkets in Semarang City, Central Java, Indonesia, with a purposive location determination. Those supermarkets are Giant, Superindo, Gelael, and ADA. It is a large category supermarket, famous and most visited by consumers 
in Semarang city. Respondents were selected using the accidental sampling method. The interviews were done to the respondents who unintentionally meet with researchers at the supermarket. The number of population of native chicken egg consumers is not known with certainty, so the Lemeshow formula is used to obtain the number of samples, with the following formula:

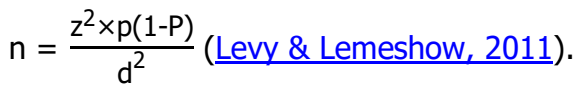

in which $\mathrm{n}$ is the number of samples, $\mathrm{z}$ is $\mathrm{z}$ value at $95 \%$ confidence interval, $\mathrm{p}$ is a maximum estimate $(=0.5), d$ is sampling error $(=10 \%)$.

The variables used in this study are age, number of family members, education level, income level, product price, product packaging, motivation, and lifestyle. The study segments consumers are based on criteria of geography (the distance of the respondent's domicile to the supermarket), demography (age, sex, level of education, number of family members and income), psychography (motivation to buy chicken eggs in supermarkets) and behavior (frequency of purchase).

The calculation results obtained as many as 96 people and rounded to 100 people. The number was allocated with the same number of 25 respondents for each supermarket. Primary data collection was done by interview using questionnaires and secondary data were obtained from books, the internet, journals, and other papers concerning the research.

The first aim of the research is to describe the market segmentation of native chicken egg consumers. The data analysis method used was a descriptive analysis by explaining a general description of the segmentation of the native chicken egg consumers market in the Semarang supermarket narratively.

The second aim of the research is to analyze the magnitude of the average value of maximum WTP for consumers of native chicken eggs. The data analysis method used was quantitative analysis, which used a Contingent Valuation Method (CVM). The CVM value can be calculated by determining the market hypothesis, determining the bids value, calculating the average value of WTP, estimating the WTP curve, and determining the aggregation of WTP.

\section{RESULT AND DISCUSSION}

\section{Profile of Consumer Respondent}

Market segmentation of native chicken egg consumers is conducted to determine the situation and condition of the respondents regarding the purchase of native chicken eggs in the Semarang City supermarkets.

a. Geographical segmentation

The result of the study (Table 1 ) shows that the majority of respondents (56\%) live in places that are close to a supermarket in a distance of equal to or less than $2.5 \mathrm{Km}$. The relatively close distance indicates that consumers consider the ease of access to fulfilling their consumption need. This finding confirms the study (Levy \& Weitz, 2012) that the majority of consumers choose shopping places that are close to home/workplace, and those that are easily accessed from any direction without road congestion (Dwirachmawati, 2014).

b. Demographic segmentation

Demographic segmentation conducted aims to map the consumer based on consumer characteristics. Table 1 shows that majority of respondents are in the productive age of $25-50$ years. The age criteria refer to the ability to take action in determining the decision to buy native chicken eggs. The age group also has a high interest in a healthy lifestyle, or someone's age can provide benefits in their lives. Meanwhile, most people at the age of more than 50 years have a body's immune which tends to decrease, so that it requires more and more healthy and nutritious food. In these conditions, a person is required to eat healthy and nutritious foods. Older people are encouraged to consume food that prioritizes quality over quantity. Food quality for older people must meet adequate nutritional need (Fitriani, 2012)

Table 1 also shows that the number of female respondents (89 people) is much more compared to male respondents (11 people). It shows that females more often go to the supermarket by taking knowledge and information about the benefits of the product. Tooy (2015) stated that women go shopping with a prepared plan from home and cognitive knowledge factors, in which by doing so, women are more dominant than men. Furthermore, Hanifawati et al. (2017) said that the intensity of shopping for women is higher and tends to buy products by paying attention to the quality of the products. 
Moreover, the result of the study shows that the educational background of consumers is generally at a high level of education or $51 \%$ is a university graduate. According to Sumarwan (2015), the higher a person's education level, the better the way of thinking in dealing with a problem or decision in purchasing an item. The influence on the purchasing decisions of the respondents is related to the level of knowledge and awareness of the respondents in consuming food that is healthy and can provide benefits to the human body.

Table 1. Characteristics of Respondent Purchasing Native Chicken Eggs in Semarang Supermarkets

\begin{tabular}{|c|c|c|c|c|c|}
\hline Variable & Giant & Gelael & Superindo & ADA & Percentage \\
\hline & \multicolumn{4}{|c|}{..................... people ...................... } & $\%$ \\
\hline Distance from home to a superma & & & & & \\
\hline$<2.5 \mathrm{~km}$ & 6 & 14 & 20 & 16 & 56 \\
\hline $2.5-5 \mathrm{~km}$ & 14 & 8 & 3 & 6 & 31 \\
\hline $5-7.5 \mathrm{~km}$ & 4 & 3 & 2 & 1 & 10 \\
\hline $7.5-10 \mathrm{~km}$ & 1 & 0 & 0 & 2 & 3 \\
\hline \multicolumn{6}{|l|}{ Age } \\
\hline Less than 25 year & 3 & 1 & 3 & 7 & 14 \\
\hline $25-50$ year & 14 & 15 & 14 & 7 & 50 \\
\hline More than 50 year & 8 & 9 & 8 & 11 & 36 \\
\hline \multicolumn{6}{|l|}{ Sex } \\
\hline Female & 25 & 23 & 22 & 19 & 89 \\
\hline Male & 0 & 2 & 3 & 6 & 11 \\
\hline \multicolumn{6}{|l|}{ Level of education } \\
\hline Elementary School & 3 & 1 & 8 & 0 & 12 \\
\hline Junior and Senior High School & 12 & 9 & 3 & 13 & 37 \\
\hline University & 10 & 15 & 14 & 12 & 51 \\
\hline \multicolumn{6}{|l|}{ Number of family members } \\
\hline$<4$ people & 13 & 15 & 15 & 16 & 59 \\
\hline $5-6$ people & 8 & 7 & 6 & 9 & 30 \\
\hline > 6 people & 4 & 3 & 4 & 0 & 11 \\
\hline \multicolumn{6}{|l|}{ Income } \\
\hline$<2.5$ million rupiahs/month & 3 & 0 & 5 & 4 & 12 \\
\hline 2.5- 3.5 million rupiahs/month & 13 & 8 & 7 & 11 & 39 \\
\hline > 3.5 million rupiahs/month & 9 & 17 & 13 & 10 & 49 \\
\hline \multicolumn{6}{|l|}{ Motivation } \\
\hline Ownself & 7 & 10 & 5 & 8 & 30 \\
\hline Family & 18 & 15 & 20 & 17 & 70 \\
\hline \multicolumn{6}{|l|}{ Frequency of purchase } \\
\hline 1 times/week & 20 & 20 & 23 & 22 & 85 \\
\hline 2 times/week & 5 & 4 & 0 & 3 & 12 \\
\hline$>3$ times/week & 0 & 1 & 2 & 0 & 3 \\
\hline
\end{tabular}

Meanwhile, the number of family members of the respondents is categorized as small families, i.e. less than or equal to four. It is in line with the National Family Planning Coordinating Board (BKKBN) definition, the small families are family members of less than or equal to 4 people. Utami (2011) further stated that the number of members influences the selection and fulfillment of food nutrition consumption in a family. The small number of family members will increase the consumption of staple products.

Furthermore, the majority of consumers of native chicken eggs come from high-income levels (49\%), with more than 3.5 million rupiahs per month. It exceeds the regional minimum wage in Semarang of 2.5 million rupiahs per month. Consumers with higher incomes are likely to buy and consume native chicken eggs even though the price of native chicken eggs is more expensive. Consumers with higher incomes tend to pay more attention to quality than quantity. This shows that the level of one's income influences the decision in purchasing native chicken eggs. These results are in line with Sriwaranun et al. (2015) who stated that WTP for products at higher prices and the incomes have a positive relationship. According to Rahayu, Hapsari, \& Adam et al. (2017), consumers who have high incomes prioritize the 
health benefits obtained from consuming the product disregard the price of the product.

c. Psychographic segmentation

Psychographic segmentation based on motivation (reasons for buying and consuming native chicken eggs) at Semarang supermarkets shows that majority of respondents coming from families by $70 \%$ and themselves by $30 \%$. Family motivation is the motivation that comes from outside or influence from others in doing something. This shows that respondents buy and consume native chicken eggs to meet the need of the family and that can be at the request or desire of the husband, wife, parents, and children. Suardika, Ambarawati, \& Sukaatmadja (2014) and Ikasari et al. (2016) said that extrinsic motivation is motives that come from the influence of others such as the encouragement of family and environment to do something.

d. Purchase behavior segmentation

Table 1 shows that the highest frequency of purchase of native chicken eggs is once a week (85\%). It shows how much consumers need for a product or how often they buy to meet the need of the consumption of native chicken eggs in Semarang supermarkets. Zulaicha \& Irawati (2016) stated that the more often the product is purchased, it indicates that the product is favored by consumers. Consumers buy native chicken eggs because of the benefits offered by native chicken eggs for health benefits (Yuniati \& Almasyhuri, 2012).

\section{Product Packaging}

Native chicken egg product is one of the ingredients of poultry chicken origin food of high nutritional value. The native chicken eggs are usually packed in rattan and mica materials that each pack contains 6 items. The number of respondents purchasing native chicken eggs presented in Table 2.

Table 2. Distribution of Native Chicken Eggs Purchases by Respondents

\begin{tabular}{lcc}
\hline $\begin{array}{l}\text { Type of } \\
\text { Packaging }\end{array}$ & $\begin{array}{c}\text { Number of } \\
\text { Respondents }\end{array}$ & $\begin{array}{c}\text { Average Purchases } \\
\text { by Respondents }\end{array}$ \\
\hline Rattan & people & $\%$ \\
Mica & 31 & 7.75 \\
\hline
\end{tabular}

The number of respondents who bought rattan packaging was 31 people with an average purchase of respondents $7.75 \%$ and the number of respondents who bought with mica packaging was 69 people with an average purchase of respondents $17.25 \%$.

The number of respondents who bought native chicken eggs in rattan packaging is fewer because its price is more expensive. Rattan packaging takes additional costs incurred from bamboo materials and is considered more environmentally friendly. This finding confirms Hantoro \& Soewito (2018) and Fakhruzy (2018) who stated that packaging with natural materials (bamboo and leaves) is made without using chemicals hence environmentally friendly and the strength of bamboo is not inferior to synthetic packaging.

Table 3. Characteristics of Respondents Based on WTP at Higher Prices for Native Chicken Products

\begin{tabular}{|c|c|c|}
\hline Variable & Yes & No \\
\hline & $\ldots .$. & ....... \\
\hline \multicolumn{3}{|l|}{ Age } \\
\hline$<25$ year & 5 & 9 \\
\hline $25-50$ year & 47 & 3 \\
\hline$>50$ year & 35 & 1 \\
\hline \multicolumn{3}{|l|}{ Sex } \\
\hline Female & 76 & 12 \\
\hline Male & 11 & 1 \\
\hline \multicolumn{3}{|l|}{ Level of education } \\
\hline Elementary School & 3 & 9 \\
\hline Junior and Senior High School & 34 & 3 \\
\hline University & 50 & 1 \\
\hline \multicolumn{3}{|l|}{ Number of family members } \\
\hline$<4$ people & 54 & 5 \\
\hline $5-6$ people & 29 & 1 \\
\hline$>6$ people & 4 & 7 \\
\hline \multicolumn{3}{|l|}{ Income } \\
\hline$<2.5$ million rupiahs/month & 2 & 10 \\
\hline $2.5-3.5$ million rupiahs/month & 37 & 2 \\
\hline > 3.5 million rupiahs/month & 48 & 1 \\
\hline \multicolumn{3}{|l|}{ Price of the native chicken egg } \\
\hline$<25$ thousand rupiahs/pack & 67 & 11 \\
\hline $25-30$ thousand rupiahs/pack & 19 & 2 \\
\hline$>30$ thousand rupiahs/pack & 1 & 0 \\
\hline \multicolumn{3}{|l|}{ Packaging type } \\
\hline Rattan & 28 & 3 \\
\hline Mica & 59 & 10 \\
\hline \multicolumn{3}{|l|}{ Motivation } \\
\hline Ownself & 25 & 5 \\
\hline Family & 62 & 8 \\
\hline \multicolumn{3}{|l|}{ Frequency of purchase } \\
\hline 1 times/week & 44 & 5 \\
\hline 2 times/week & 17 & 3 \\
\hline$>3$ times/week & 26 & 5 \\
\hline
\end{tabular}

\section{Willingness to Pay}

The result of the study (Table 3 ) shows that the older people indicates the higher WTP than the normal price because they have better environmental awareness and healthy lifestyle. Likewise, the higher 
the education level of respondents, the higher the level of knowledge and awareness about the importance of health (Sumarwan, 2015). The higher the respondent's income, the more concerned with the health benefits obtained from a product he consumes and the price paid (Rahayu et al., 2017).

In summary, the result shows that 87 respondents show WTP more than the current price to get a native chicken egg product. The higher WTP is described by the respondents who are in the age range of 25 to 50 years, have the number of family members is fewer than or equal to 4 people, graduated the college/university, have a monthly income of more than 3,5 million rupiahs, buy native chicken eggs at 25 thousand rupiahs per pack, purchase in mica packaging, buy as the motivation family reason, and go shopping in once a week.

Table 4. Number of Respondents Who are WTP Additional Price

\begin{tabular}{cc}
\hline Additional Price of WTP & Respondents \\
\hline$\%$ & people \\
5 & 35 \\
10 & 23 \\
15 & 9 \\
20 & 20 \\
Total & 87 \\
\hline
\end{tabular}

Furthermore, this study shows that the magnitude of WTP (87 respondents) of native chicken egg ranged from 5 to $20 \%$ higher than the existing price, with the distribution presented in Table 4. The WTP range between 5 to $10 \%$ was found to be the highest, while respondents' responses to the WTP more than $10 \%$ displayed a sharp decrease. The results of this study are similar to Hamzaoui \& Zahaf (2012), who stated that most consumers do not respond on WTP more than $10 \%$ of the normal price.

However, Table 4 also shows that there is a significant response, where respondents show WTP at higher prices for native chicken eggs up to $20 \%$. This group of respondents is mostly college university graduates, in which the influence in purchasing decisions is related to the level of knowledge and awareness in consuming healthy foods and can provide benefits to the body. According to Sumarwan (2015), the higher a person's education, the better the way of thinking in dealing with a problem or decision in purchasing an item.

\section{Maximum Willingness to Pay}

The analysis of consumers' WTP for native chicken egg products is done using the (CVM) to determine the average WTP of consumers. The results of the calculation of the average of maximum WTP for native chicken egg consumers are presented in Table 5.

Table 5. Average of Maximum WTP of Native Chicken Eggs in Supermarkets

\begin{tabular}{lccc}
\hline $\begin{array}{l}\text { Supermarket and } \\
\text { Packaging*) }\end{array}$ & $\begin{array}{c}\text { Initial } \\
\text { Price }\end{array}$ & $\begin{array}{c}\text { Average of } \\
\text { Maximum } \\
\text { WTP }\end{array}$ & $\begin{array}{c}\text { Additional } \\
\text { increase }\end{array}$ \\
\hline Giant & .. thousand rupiahs.. & $\%$ \\
$\quad$ Rattan & 23.50 & 25.51 & 8.57 \\
$\quad$ Mica & 20.90 & 24.36 & 16.55 \\
Gelael & & & \\
$\quad$ Rattan & 20.95 & 24.97 & 19.16 \\
$\quad$ Mica & 17.95 & 20.74 & 15.55 \\
Superindo & & & \\
$\quad$ Rattan & 24.99 & 26.79 & 7.22 \\
$\quad$ Mica & 18.95 & 20.47 & 8.00 \\
ADA & & & \\
$\quad$ Rattan & 23.10 & 25.41 & 10.00 \\
$\quad$ Mica & 18.00 & 19.38 & 7.64 \\
Average & & & \\
$\quad$ Rattan & 23.14 & 25.67 & 11.23 \\
Mica & 18.95 & 21.24 & 11.93 \\
\hline
\end{tabular}

The result of the study (Table 5) shows that the maximum value of WTP for native chicken egg products varies depending on the price and the willingness of consumers to pay higher than the current price. The average maximum WTP value for all packages (rattan and mica) is 23.45 thousand rupiahs. The highest average of maximum WTP found in rattan packaging in Superindo is 26.79 thousand rupiahs, while the lowest average maximum WTP discovered in mica packaging in ADA is 19.37 thousand rupiahs.

Table 4 also presents the additional increase in maximum WTP compared to the initial price. An additional increase of WTP from all native chicken products ranged from 7.22 to $19.16 \%$, with an average increase of $11.58 \%$. According to Krystallis \& Chryssohoidis (2005), the maximum WTP that is willing to be issued or paid more by consumers depends on the type and price of the food product. Furthermore Eka, Wibowo, \& Mustapit (2019) revealed that the average maximum WTP of the organic egg is Rp 29.5 thousand rupiahs per pack (10 eggs). 


\section{Willingness to Pay Curve}

The respondent's WTP curve is formed from the $X$ and $Y$ axes, where the $X$-axis represents the cumulative number of respondents who choose a WTP and the Y-axis represents the WTP itself. The presentation of graphic images on the $X$-axis is presented upside down to show an estimate of the aggregate amount of consumer surplus.

The results (Figure 1 ) show that the WTP curves of the native chicken egg in the mica (right) and

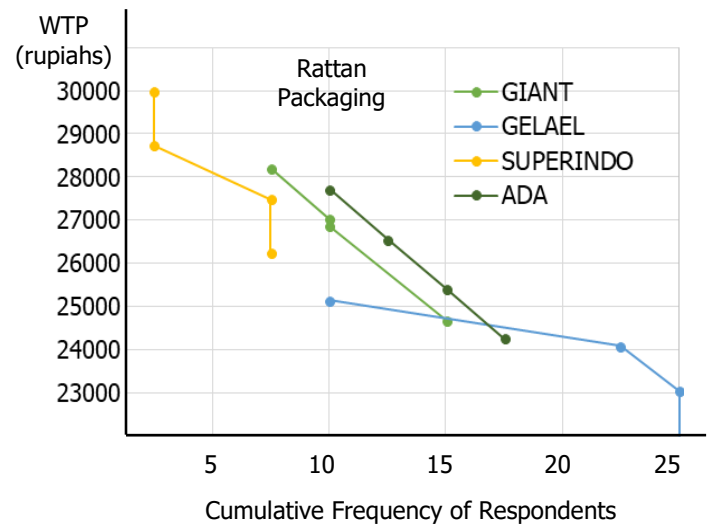

rattan (left) packages in the Semarang City supermarket, respectively. The figure shows that the curve moving from top left to bottom right resembles the shape of the demand curve. WTP curves illustrate the amount of accumulation of people to the value of WTP for a product. The WTP curve has a negative slope, which means that the higher the value of the WTP, the less the number of people who shows WTP. Conversely, the lower the WTP, the more people state their WTP to get a certain product.

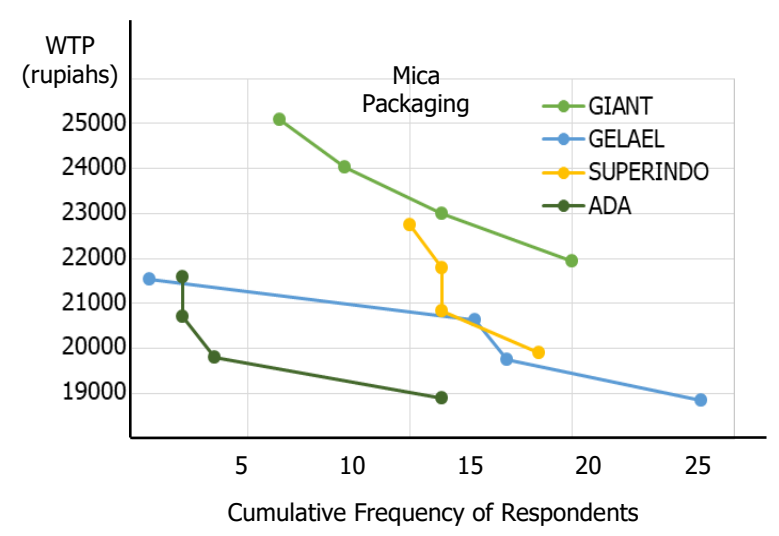

Figure 1. WTP curves of native chicken eggs (left: rattan packaging; right: mica packaging)

Respondents assume that the benefits of native chicken eggs consumed are more valuable than the money being paid. Therefore, respondents show their WTP at higher price. This is following the statement of Prayana \& Yuliarmi (2020) who stated that consumers take WTP more for a product because of their high level of awareness and health care. This is also supported by the study of Aufanada, Ekowati, \& Prastiwi (2017), which shows the movement of the WTP curve for describing the situation where respondents are ready to pay a higher price. The finding of Mengistie (2020) reveals that the willingness to pay about 5 to $50 \%$ above teh premium price of organic products can be viewed as the cost of investment in human health.

\section{Aggregation of Willingness to Pay}

Aggregation of the total WTP native chicken eggs is the overall value of the values willing to be paid by all respondents in the study. WTP aggregation was obtained by using the average value of WTP multiplied by the number of respondents who show their WTP. The results of the calculation of aggregation of WTP native chicken eggs are presented in Table 6.

Table 6. Aggregate WTP of Native Chicken Eggs in Supermarket

\begin{tabular}{lcc}
\hline \multirow{2}{*}{ Supermarket } & \multicolumn{2}{c}{ WTP Aggregation by Packaging } \\
\cline { 2 - 3 } & Mica & Rattan \\
\hline Giant & $\ldots$. thousand rupiahs .... \\
Gelael & 341 & 158 \\
Superindo & 373 & 149 \\
ADA & 204 & 241 \\
\hline
\end{tabular}

The WTP aggregation has different values in each location and packaging type. The highest WTP aggregation value is sold in Gelael with mica packaging at the 373 thousand rupiahs. Meanwhile, the lowest WTP aggregation is found in Gelael with rattan packaging at 149 thousand rupiahs. The high value of aggregation in Gelael with mica packaging is due to high product prices and the frequency of respondents who pay more than the current price, which was as many as 18 people. Meanwhile, the native chicken eggs in Gelael with rattan packaging have low purchase frequency. It was only 6 of 100 
respondents. Different aggregation values are caused by differences in prices and the maximum value that respondents are ready to pay. This is following the opinion of Krystallis \& Chryssohoidis (2005) who stated that the value of maximum WTP and aggregation value of WTP very depends on the price of the product and the type of product.

\section{Research Implication}

First, the perception of the price of native chicken eggs that is considered expensive is an obstacle for producers. In determining the selling price, it is important to know how much consumers purchasing native chicken eggs. This study emphasizes that consumer market segmentation includes geographic, demographic, psychographic, and behavioral segmentation. Consumer market segmentation can be a reference and substantial evaluation for supermarkets to understand consumer perceptions so that products can meet the need and desires of consumers precisely. Gil, Gracia, \& Sánchez (2000) in his research on market segmentation and consumers' WTP for organic food products in Spain stated that high production costs and distribution margins lead to high selling prices, therefore information on the maximum value of WTP is needed. This information can support producers to implement an adequate pricing strategy for food products. The native chicken farm business is fundamentally relatively profitable from the producers' side. Native chicken farmers relatively do not hold on production costs as broiler chicken businesses, which require the supply of feed, seed, and cage maintenance (Suwarta \& Hanafie, 2018).

Second, variables such as age, gender, income, and education are the most important factors affecting WTP analysis of native chicken eggs. Other main factors affecting WTP include the number of family members, product prices, product packaging, motivation, and lifestyle. The older people are the higher the WTP compared to the existing price. In general, older people show better environmental awareness and a healthy lifestyle. Moreover, more WTP will be exhibited by the higher the education level, knowledge, and awareness about the importance of health. The higher the respondent's income will see the importance of the health benefits obtained from a product disregard the price side. Aufanada, Ekowati, \& Prastiwi (2017) stated that among the factors found to affect WTP include gender, age, income, and education.

Third, consumers consider native chicken eggs as healthy, nutritious, and delicious food. In this study, $87 \%$ of respondents present WTP more to purchase native chicken eggs. This can reinforce the finding of Güney \& Giraldo (2019) in which the motivation to consume organic accordance with the individual benefits that have a greater impact than collectivist benefits on consumer choices for buying organic eggs. Furthermore, native chicken eggs are as a source of healthy and nutritious food ingredients need more attention. This implication can affect various parties in the native chicken egg business chain. The government can take a role in terms of education and health to encourage the formation of healthy and quality of the human resources. Native chicken farmers need to be encouraged to innovate to increase chicken egg production that meets the standards of poultry farming. Supermarkets as hubs of the trade chain can play a role in implementing quality standards for quality native chicken egg products.

\section{CONCLUSION AND SUGGESTION}

Consumers characteristics that are based on the geographical, demographic, psychographic, and behavioral segmentation can be viewed as important for research analysis of WTP of the native chicken eggs. The distance of domicile to the supermarket becomes the consideration of consumers to buy native chicken eggs in Semarang city. Consumer respondents of the native chicken egg show primary characteristics such as majority (50\%) in between 25 to 50 years old, female (89\%), the number of family members of fewer or 4 people $(59 \%)$, university graduate $(50 \%)$, go shopping as family motivation (70\%), go supermarket once a week (85\%). Whereas, the maximum WTP for native chicken egg consumers is 23.45 thousand rupiahs per pack (@ 6 eggs). The highest of maximum WTP found in rattan packaging in Superindo is 26.79 thousand rupiahs per pack. The highest WTP aggregation value was found in Gelael with mica packaging at the 373 thousand rupiahs.

This research suggests that the government can educate and disseminate information and benefits of native chicken eggs to the community. This socialization will increase public awareness and 
awareness to better understand the benefits and importance of native chicken eggs. Supermarkets as a link between supply chains and trade systems can pay more attention to applyi quality standards for native chicken eggs and to protect the interests of consumers.

\section{REFERENCES}

Astawan, M., \& Kasih, A. L. (2008). Khasiat WarnaWarni Makanan. PT Gramedia Pustaka Utama. https://books.google.co.id/books?id=6y2eu0xw7s $4 \mathrm{C}$

Aufanada, V., Ekowati, T., \& Prastiwi, W. D. (2017). Kesediaan membayar (willingness to pay) konsumen terhadap produk sayur organik di pasar modern Jakarta Selatan. AGRARIS: Journal of Agribusiness and Rural Development Research, 3(2), 1-18. https://doi.org/10.18196/agr.3246

Bishop, K. C., \& Timmins, C. (2019). Estimating the marginal willingness to pay function without instrumental variables. Journal of Urban Economics, 109, January, 66-83. https://doi.org/10.1016/j.jue.2018.11.006

BPS Kota Semarang. (2015). Kota Semarang dalam Angka 2015. Badan Pusat Statistika Kota Semarang, Provinsi Jawa Tengah. Retrieved from https://semarangkota.bps.go.id/publication/2015/ 11/20/61675a12844d75acad374b16/kotasemarang-dalam-angka-2015.html

Diana, F. M. (2013). Omega 3 dan kecerdasan anak. J. Kesehatan Masyarakat, 7(2), 82-88. https://doi.org/10.24893/jkma.v7i2.113

Dwirachmawati, M. (2014). Pengaruh bauran pemasaran ritel terhadap keputusan pembelian produk di Hypermart Ponorogo City Center. Jurnal Pendidikan Tata Niaga, 2(2), 47-57. Retrieved from

https://jurnalmahasiswa.unesa.ac.id/index.php/jp tn/article/view/8151

Eka, O., Wibowo, R., \& Mustapit. (2019). Analisis kesediaan membayar (willingness to pay) produk Telur Organic Srikandi di Kabupaten Jember. Pertanian, Retrieved from https://library.unej.ac.id/index.php?p=show_detai I\&id=192673\&keywords=

Fadilah, R., \& Fatkhuroji. (2013). Memaksimalkan Produksi Ayam Ras Petelur. PT AgroMedia Pustaka. https://books.google.co.id/books?id=hidGAgAAQB AJ
Fakhruzy. (2018). Fibrilasi selulosa bambu ampel (Bambussa vulgaris). Menara Ilmu, 12(1), 227$230 . \quad$ Retrieved from https://jurnal.umsb.ac.id/index.php/menarailmu/a rticle/view/558

Fernandez, A. M. (2020). Price sensitivity versus ethical consumption: a study of millennial utilitarian consumer behavior. Journal of Marketing Analytics, 8(2), 57-68. https://doi.org/10.1057/s41270-020-00074-8

Fitriani, E. (2012). Pola kebiasaan makan orang lanjut usia (studi kasus: penderita penyakit hipertensi sukubangsa minangkabau di Jakarta). Humanus, 12(2), 134. https://doi.org/10.24036/jh.v11i2.2162

Gil, J. M., Gracia, A., \& Sánchez, M. (2000). Market segmentation and willingness to pay for organic products in Spain. International Food and Agribusiness Management Review, 3(2), 207$226 . \quad$ https://doi.org/10.1016/s10967508(01)00040-4.

Güney, O. I., \& Giraldo, L. (2019). Consumers' attitudes and willingness to pay for organic eggs: A discrete choice experiment study in Turkey. British Food Journal, 122(2), 678-692. https://doi.org/10.1108/BFJ-04-2019-0297 .

Hamzaoui, L., \& Zahaf, M. (2012). Canadian organic food consumers' profile and their willingness to pay premium prices. Journal of International Food and Agribusiness Marketing, 24(1), 1-21. https://doi.org/10.1080/08974438.2011.621834

Hanifawati, T., Suryantini, \& Mulyo, J. H. (2017). Pengaruh atribut kemasan makanan dan karakteristik konsumen terhadap pembelian. Agriekonomika, 6(1), 72-85 https://doi.org/10.21107/agriekonomika.v6i1.189 5

Hantoro, M. R., \& Soewito, B. M. (2018). Eksplorasi desain kemasan berbahan bambu sebagai produk oleh-oleh premium dengan studi kasus produk makanan UKM Purnama Jati Jember. Jurnal Sains dan Seni ITS, 7 (1), 1-4. https://doi.org/10.12962/j23373520.v7i1.30041

Hidayat, C., \& Asmarasari, S. A. (2015). Native chicken production in Indonesia: a review. Jurnal Peternakan Indonesia (Indonesian Journal of Animal Science), 17 (1), 1-11. https://doi.org/10.25077/jpi.17.1.1-11.2015

Ikasari, D. M., Deoranto, P., Lutfian, R., \& Silalahi, R. (2016). Factors influencing consumers behaviour towards the decision on purchasing organic rice. Jurnal Teknologi Pertanian, 17(1), 69-78. 
Retrieved

from

https://jtp.ub.ac.id/index.php/jtp/article/view/565

Johnson, A. M., Abdoulaye, T., Ayedun, B., Fulton, J. R., Widmar, N. J. O., Adebowale, A., Bandyopadhyay, R., \& Manyong, V. (2020). Willingness to pay of Nigerian poultry producers and feed millers for aflatoxin-safe maize. Agribusiness, 36(2), 299-317. https://doi.org/10.1002/agr.21621

Krystallis, A., \& Chryssohoidis, G. (2005). Consumers' willingness to pay for organic food. British Food Journal, $107(5)$, https://doi.org/10.1108/00070700510596901

Levy, M. \& Weitz, B. A. (2012). Retailing Mangement 8th edition. McGraw-Hill/Irwin, 675p https://books.google.co.id/books?id=PstaLwEACA AJ

Levy, P. S., \& Lemeshow, S. (2011). Sampling of Populations: Methods and Applications: Fourth Edition. Sampling of Populations: Methods and Applications: Fourth Edition. Wiley Blackwell. 578p. https://doi.org/10.1002/9780470374597

Lupu, J. S. I, Wuri, D. A, \& Detha, A. I. R. (2016). Perbandingan kualitas telur ayam kampung yang disimpan pada suhu ruang dan suhu lemari pendingin ditinjau dari tinggi kantung hawa, indeks kuning telur, indeks albumin, haugh unit dan total plate count (TPC). Jurnal Veteriner Nusantara, 1(1), 46-52. Retrieved from http://ejurnal.undana.ac.id/jvn/article/view/931

Mengistie, B. (2020). Consumers' awareness on their basic rights and willingness to pay for organic vegetables in Ethiopia. Journal of Socioeconomics and Development, 3(1), 1-15. doi:http://dx.doi.org/10.31328/jsed.v3i1.1278

Pramudiana, D. (2017). Perubahan perilaku konsumtif masyarakat dari pasar tradisional ke pasar modern. Asketik, 1(1), 35-43. https://doi.org/10.30762/ask.v1i1.409

Prayana, I. M. D., \& Yuliarmi, N. N. (2020). Factors affecting the purchase of local agricultural commodities. Russian Journal of Agricultural and Socio-Economic Sciences, 101(5), 47-57. https://doi.org/10.18551/rjoas.2020-05.05

Rahayu, A. D., Hapsari, T. D., \& Adam, J. (2017). Analisis kesediaan membayar (willingness to pay) beras cerdas CV AN-Nahlah di Kabupaten Jember. Journal of Social and Agricultural Economics, 10(1), 17-30. https://doi.org/10.19184/jsep.v10i1.5211

Sriwaranun, Y., Gan, C., Lee, M., \& Cohen, D. A. (2015). Consumers' willingness to pay for organic products in Thailand. International Journal of Social Economics, 42(5), 480-510. https://doi.org/10.1108/IJSE-09-2013-0204

Suardika, I., Ambarawati, I., \& Sukaatmadja, I. (2014). Analisis perilaku konsumen terhadap keputusan pembelian sayur organik CV Golden Leaf Farm Bali. Jurnal Manajemen Agribisnis, 2(1), 480-510. Retrieved from https://ojs.unud.ac.id/index.php/agribisnis/article/ view/9942

Sumarwan, U. (2015). Perilaku Konsumen: Teori dan Penerapannya dalam Pemasaran. Ghalia Indonesia. Retrieved from http://publikasi.mb.ipb.ac.id/wpcontent/uploads/2013/03/2011-UJANGSUMARWAN-PERILAKU-KONSUMEN.pdf

Suwarta, S., \& Hanafie, R. (2018). The influence of business management on income and the risk of income in the broiler chicken farming. Journal of Socioeconomics and Development, 1(1), 25-31. http://dx.doi.org/10.31328/jsed.v1i1.520

Tooy, S. M. (2015). Analisis perbedaan perilaku impulse buying konsumen laki-laki dan perempuan berdasarkan proses afektif dan kognitif. Riset Bisnis dan Manajemen, 3(2), 111126. Retrieved from https://ejournal.unsrat.ac.id/index.php/jrbm/articl e/view/8398

Utami, D. P. (2011). Analisis pilihan konsumen dalam mengkonsumsi beras organik di Kabupaten Sragen. Mediagro, 7(1), 41-58. Retrieved from https://publikasiilmiah.unwahas.ac.id/index.php/ Mediagro/article/view/566

Yang, Y. C. (2018). Factors affecting consumers' willingness to pay for animal welfare eggs in Taiwan. International Food and Agribusiness Management Review, 21(6), 741-754. https://doi.org/10.22434/IFAMR2017.0072

Yuniati, H., \& Almasyhuri. (2012). Vitamin B6, B9, $B 12$ and $E$ content of several types of meats, eggs, fishes and marine shrimps in Bogor and surrounding areas. Penelitian Gizi dan Makanan (The Journal of Nutrition and Food Research), 35(1), 78-89. Retrieved from http://ejournal.litbang.kemkes.go.id/index.php/pg $\mathrm{m} /$ article/view/3086

Zulaicha, S., \& Irawati, R. (2016). Pengaruh produk dan harga terhadap keputusan pembelian konsumen di Morning Bakery Batam. Inovbiz: Jurnal Inovasi Bisnis, 4(2), 123. https://doi.org/10.35314/inovbiz.v4i2.76 